\title{
PReS-FINAL-2060: The role of stress factors in the onset of juvenile idiopathic arthritis
}

\author{
N Stepanenko, T Shelepina, I Nikishina* \\ From 20th Pediatric Rheumatology European Society (PReS) Congress \\ Ljubljana, Slovenia. 25-29 September 2013
}

\section{Introduction}

According to the data found in the literature on clinical psychology, RA refers to the group of psychosomatic diseases, the leading role in occurrence of which is played by negative life events that cause stress.

\section{Objectives}

To compare the frequency of negative life events in the areas of family, education, communication with peers in patients with LA before the occurrence of the disease and in a control group of nominally healthy children.

\section{Methods}

The biographical methodology of "The life line", the picture of the family, drawings "I am at school", "Me and my friend" and a clinical interview.

\section{Results}

See Table 1.

\section{Conclusion}

A statistically significant increase in the frequency of family stress in patients in the period preceding the onset of LA was revealed.

\section{Disclosure of interest}

None declared.

Published: 5 December 2013

doi:10.1186/1546-0096-11-S2-P72

Cite this article as: Stepanenko et al:: PReS-FINAL-2060: The role of stress factors in the onset of juvenile idiopathic arthritis. Pediatric

Rheumatology 2013 11(Suppl 2):P72.

\section{Table 1}

\begin{tabular}{|c|c|c|c|c|c|c|c|c|}
\hline \multirow{3}{*}{$\begin{array}{l}\text { Areas } \\
\text { Family }\end{array}$} & \multicolumn{4}{|c|}{$\begin{array}{l}\text { The main group comprised } 30 \text { patients with various } \\
\text { LA at the age of } 7 \text { to } 13 \text { years (in all, } 152 \text { events) }\end{array}$} & \multicolumn{4}{|c|}{$\begin{array}{l}\text { The control group of nominally healthy children with no } \\
\text { articular pathology comprised } 10 \text { persons aged between } 8 \text { and } \\
14 \text { years old (in all, } 76 \text { events) }\end{array}$} \\
\hline & \multicolumn{2}{|c|}{ Positive events } & \multicolumn{2}{|c|}{ Negative events } & \multicolumn{2}{|c|}{ Positive events } & \multicolumn{2}{|c|}{ Negative events } \\
\hline & 48 & $31.6 \%$ & 94 & $\begin{array}{l}61.8 \\
\% P=0.000\end{array}$ & 23 & $30 \%$ & 16 & $21 \%$ \\
\hline Education & 34 & $22.4 \%$ & 10 & $6.6 \%$ & 12 & $15.8 \%$ & 7 & $9.2 \%$ \\
\hline Communication & 9 & $5.9 \%$ & 3 & $2 \%$ & 10 & $13 \%$ & 8 & $10 \%$ \\
\hline
\end{tabular}

